University of Chicago Law School

Chicago Unbound

Journal Articles

Faculty Scholarship

1988

\title{
Market and Regulatory Approaches to Medical Malpractice: The Virginia Obstetrical No-Fault Statute
}

Richard A. Epstein

Follow this and additional works at: https://chicagounbound.uchicago.edu/journal_articles

Part of the Law Commons

\section{Recommended Citation}

Richard A. Epstein, "Market and Regulatory Approaches to Medical Malpractice: The Virginia Obstetrical No-Fault Statute," 74 Virginia Law Review 1451 (1988).

This Article is brought to you for free and open access by the Faculty Scholarship at Chicago Unbound. It has been accepted for inclusion in Journal Articles by an authorized administrator of Chicago Unbound. For more information, please contact unbound@law.uchicago.edu. 


\title{
MARKET AND REGULATORY APPROACHES TO MEDICAL MALPRACTICE: THE VIRGINIA OBSTETRICAL NO-FAULT STATUTE
}

\author{
Richard A. Epstein*
}

\section{The Who and the What of Medical Malpractice}

THE question of medical malpractice and its legal consequences has long been of concern to lawyers and physicians. For years, however, it seemed to be a problem that was well in control, given the standard array of doctrines and practices that have grown up around it. Today, medical care on average is probably better and more sophisticated than it has ever been before. Yet since roughly $1975,{ }^{1}$ the medical profession has regarded itself as under siege by a set of legal developments, which both lawyers and judges have defended as merely the regular and traditional application of the ordinary rules of civil responsibility to physicians, who are, after all, no more special than anyone else.

Everyone cannot be right, but everyone can be wrong. With respect to medical malpractice, $I$ think that this second possibility is too close to the truth. There are essentially two general questions that have to be decided in fashioning any system of medical malpractice responsibility. First, who should decide the applicable norms for a given transaction? Second, what should those norms be? The traditional view of the subject has been that the first of these questions is easy to answer, whereas the second is more difficult. On the imitial

* The James Parker Hall Distinguished Service Professor of Law, University of Chicago. This Article was commissioned by the Institute of Medicine's Committee on the Effects of Medical Professional Liability on the Delivery of Maternal and Child Health Care, in Washington D.C. The paper was presented at the committee's research symposium on June 20, 1988 [hereinafter Research Symposium], and will appear in the forthcoming book, The Effects of Medical Professional Liability on the Delivery of Maternal and Child Health Care (J. Bulger \& V. Rostow eds. 1989) [hereinafter Maternal Health]. I would like to thank Victoria Rostow of the Institute for interesting me in this project, and James Fiero for lis valuable research assistance.

1 This was the year of the first major physician revolt against malpractice insurance premium increases in such major states as California, Illinois, and New York. See Kotulak, Malpractice Suits-Growing Sickness, Chi. Tribune, May 11, 1975, $\S 1$, at 1, col. 1; Malpractice: MD's Revolt, Newsweek, June 9, 1975, at 59. 
question of the allocation of power, the applicable standards should be set up either by courts or by legislatures, where the latter can override the judgment of the former unless and until it infringes the constitutional rights of individual patients. With the locus of power thus established, the debate then switches to the choice of collective standards applicable across the board. What are the rules for inforined consent, for setting the standard of care, for proving the breach of duty, for measuring damages, or for taking collateral sources of compensation into account? The number of perinutations within the framework of a tort medical malpractice system is legion. The set of possibihities is augmented yet again by more radical proposals that jettison the "fault" standard and proceed on wholly different no-fault principles. ${ }^{2}$ Generally, obstetrics and gynecology are not regarded as requiring special rules-and justifiably so. The Virginia BirthRelated Neurological Injury Compensation Act (Injured Infant Act), ${ }^{3}$ discussed in greater detail in Part III, applies only to a himited class of obstetrical injuries and is therefore a clear, and ominous, exception to the general approach.

The common mistake in the modern systein of inedical malpractice responsibility lies in its facile answer to the first question. Why is it assumed that soine outside collective body-court or legislatureslionld liave the last word on the design of systems to deal witl medical malpractice or, if you will, inedical maloccurrences? The rival systein of private contracts between patients and physicians, who can then decide these questions for theinselves, is typically given very short shrift. ${ }^{4}$ Yet once this possibility is taken more seriously, the pressure for unanimious or substantial agreement on the substantive issues is removed. If pliysician $A$ and patient $B$ structure their arrangeinents one way, physician $C$ and patient $D$ are free to imitate

2 See Havighurst, Medical Adversity Insurance: Has Its Time Come?, 1975 Duke L.J. 1233; Havighurst \& Tancredi, Medical Adversity Insurance: A No-Fault Approach to Medical Malpractice and Quality Assurance, 613 Ins. L.J. 69 (1974).

3 Va. Code Ann. $\$ \$ 38.2-5000$ to -5021 (Supp. 1987).

4 I have defended this system more fully in Epstein, Contracting Out of the Medical Malpractice Crisis, in 20 Perspectives in Biology and Medicine 228 (1977); Epstein, Medical Malpractice: Its Cause and Cure, in The Economics of Medical Malpractice 245 (S. Rottenberg ed. 1978); Epstein, Medical Malpractice: The Case for Contract, 1976 Am. B. Found. Res. J. 87. For other defenses of the same position, see P. Danzon, Medical Malpractice: Theory, Evidence and Public Policy (1985); Robinson, Rethinking the Allocation of Medical Malpractice Risks Between Patients and Providers, Law \& Contenp. Probs., Spring 1986, at 173. 
them or to disregard that arrangement if they choose to do so. The dominant question is no longer what single set of rules shall govern all transactions, but is who shall decide which rules are applicable in any individual case. The first function of legislatures is to make clear that ordinary freedoms to contract may be exercised. The function of courts is reduced to the modest one of enforcing contracts as drafted. Thereafter, the legislature should simply stay its hand.

This last condition of legislative inaction explains why it will be so difficult to implement contract solutions: markets always operate at the mercy of legislative intervention. Moreover, there is today sustained and decisive political objection to any return to a marketplace for medical goods and services. Putting aside, for a moment, these practical political objections, I think that we can find reasons why a system of contracts and markets works for most goods and services. This general solution can then be extended to the specific problems of obstetrical care. Part II analyzes the strengths and limitations of market mechanisms. Part III then discusses the coverage and the funding rules of the Virginia Injured Infant Act.

\section{The Logic OF MARKetS}

\section{A. Why Contract?}

The basic logic of contracting is simple and appealing. Everyone generally starts with individual endowments in wealth, intelligence, and skills. Physicians have their labor; hospitáls, their resources; and patients, their wealth and natural talents. (For these purposes at least we can put aside the question of how anyone comes by any particular entitlement in the first instance.) Contracting parties also have a certam measure of self-interest, but that self-interest should not be too narrowly defined; parents, for example, have a deep concern for the welfare of their children, and will generally contract on their behalf. All parties are allowed to exchange their endowments for others, which they do not possess. The exchanges can take place on whatever terms they see fit. Force and misrepresentation, as well as contracting with infants and incompetents, however, are ruled out as improper forms of advantage-taking.

At this point, the logic of self-interest takes over, to the public good. Each side to the transaction will surrender those things that it values only if it receives in exchange things to which it attaches a greater value. Each voluntary exchange leaves both sides better off 
than they were before. Because there are no obvious negative externalities (who is hurt because $A$ 's children get better care?), the private gains to the parties are also translated into social gains. An extensive system of contracts, in which all contracts share this feature of mutual gain, should - and would - lead us toward an improved social state of affairs. Each individual exchange has led to an improvement of the welfare of the parties to the exchange. As that process has been repeated many times, the impact of the improvements is cumulative. At the end of the process, each person should be better off than he was at the outset, with nobody being left worse off. Because everyone is better off in the final state of the world than in the original one, there is a social optimum, which can even be measured by the exacting standards of Pareto optimality. ${ }^{5}$

In practice, matters will not be perfect, of course, because contracts are costly to negotiate, to draft, and to enforce. ${ }^{6}$ There comes a point at which the transaction costs of making new bargains exceed the gams that anyone could hope to derive from them. The system will therefore reach equilibrium before all potential gams from trade are exhausted. Transaction costs will prevent some wortliwhile exclianges from occurring. Nevertheless, this limitation on social welfare is a fact of life tliat can be overcome only by devising clieaper modes of contracting (for example, group contracts), whicl allow ınore bargains to go forward. It is liardly a reason for striking down those contracts that liave been able to emerge notwitlistanding these transactional obstacles.

\section{B. The Limitations on Contract}

\section{Imperfect Information}

The critical issue is this: Is there any reason why this system of bargaining is inappropriate for medical malpractice cases, botlı gener-

5 For a discussion of this exacting Pareto standard, and the alternative Kaldor-Hicks standard, whereby there is a social improvement if the winners in principle can compensate the losers for their pains out of their winnings from the transaction, see Coleman, Efficiency, Utility, and Wealth Maximization, 8 Hofstra L. Rev. 509 (1980). Note that the system of contracting, with its unanimous consent, satisfies both criteria, and does not require some very subtle social analysis to determine the relative impacts of complex regulatory prograins on both winners and losers.

6 For a formal introduction of transaction costs into modern legal and econorric thinking, see generally Coase, The Problem of Social Cost, 3 J.L. \& Econ. 1 (1960). 
ally and in the special case of obstetrics and gynecology? Several reasons can be offered. It can be argued that individuals do not have sufficient information to decide which bargains are in their best interests. There is surely reason for concern here, but the problem may be overstated. Imitially, the problem works in both directions. If individuals have imperfect information, then so do regulators, administrators, juries, and judges. To treat the question as though imperfect information runs only in one direction is to misstate the universal problems with imperfect information. Both forms of imperfect inforination-that of the consumer and that of the regulator-are critical. Furthermore, where public regulation is involved, a single set of rules must work for all those affected, notwithstanding any individual differences in taste and demand. The rules, moreover, will be prepared by persons who have no real information about the subjective preferences of the people whom they wish to protect.

Looking then to consumers, we can assume that they inake decisions with imperfect information. That is not the same, however, as their having no information at all. Moreover, in the case of consumers, the incentive structures are more favorable because the individuals who seek to get information are obtaiming it for themselves, not for the public at large. People can inake mquiries, rely upon systems of public certification, do busmess with imstitutions that have substantial reputations, and hire intermediates to nake certain decisions about who shall provide what kind of health care. The rise of health maintenance organizations (HMOs), group insurance, employer and union plans, and medical advertismg represent increased efforts to close the information gap at a reasonable cost. ${ }^{7}$ Surely, no one believes that the problems of information are so great that patients should be denied the right to choose their own physicians because patients do not have medical degrees (or because they do!). And no one believes that the right is valueless because the choice is at best random.

In general, imperfect information is a cost. Just as with other costs, market institutions that are designed to reduce those costs will arise to the extent that these institutions are cost-justified. Typically, individual patients will decide to trade off some measure of independence and some resources in order to get some, but not all, information they need. Even today, patients use the patchwork system to select hospi-

7 See P. Danzon, supra note 4, at 211. 
tals and physicians, if only because it is better than any alternative that can be devised. It is far from obvious, therefore, that a contract system must founder badly in choosing the rules to govern malpractice. Why allow freedom in the selection of physicians, but not in the choice of malpractice rules?

Medical mishaps are a common occurrence, and the issue has surely been widely addressed in the press today. People therefore contract with the expectation of gain, but with the knowledge of possible loss, especially in the medical setting. A set of rules for allocating the loss of that failure are not currently negotiated because there is no freedom of contract in that domam. Let that freedom be guaranteed, and the subject will not be some idle afterthought to the basic negotiations. Very serious attention will be given to the types of terms that can and should be imposed with respect to the potential loss. Any institution must have terms favorable enough to attract patients. Yet they cannot be so one-sided as to bankrupt those patients at the back end if, and when, somethmg goes wrong. Whenever contracts are used, both sides have to trade off gain against loss, benefit against inconvenience. For large institutions, the fact that some level of medical malpractice will occur should be accepted as a social given. There are too many cases for all to be handled correctly, no matter what level of care is taken. The task of contracting is not only to reduce these bad cases; it is also to see that the handling of bad cases does not overwhelm the system as a whole.

Today, there is extensive competition for the provision of medical services. That competition does not have to be confined to matters of price, thereby holding the minimum level of acceptable services constant by government edict. There can also be competition over the level of compensation provided in the event of a medical imishap. Terms that regulate liability for medical imishaps do not have to be kept apart from the general market processes by which agreements for medical and hospital services are formed. Experimentation and innovation are possible here. The critic who thinks that an adoption of contractual freedom automatically means that medical providers will exclude all hability for all untoward consequences should ask himself how he would respond when a rival provider offers some package of benefits to persons injured durmg the course of medical treatment. Surely, such a medical provider would not remain idle as market share and profits shrink. 
In the abstract, it is very hard to know what the precise set of optimal terms is for all medical situations. Nevertheless, it is fairly clear that the present set of legal rules is not optimal, given the decision of many professionals to exit the market, ${ }^{8}$ the incentives for excessive care that liability rules can create, and the enormous litigation costs of the system at large. The fine-tuning that is needed to improve the rules cannot be done by juries and courts who are years behind the times, and who totally lack the hands-on experience necessary to make the relevant tradeoffs. Contract solutions, on the other hand, lead to decentralization, and to the quicker dissemination of successful practices and business arrangements throughout the medical profession.

\section{Binding the Child}

There is one important qualification that apphes to obstetrical (but not gynecological) care: the physician/patient relationship is between the physician and the woman. Yet the losses may be suffered by a third party, the unborn child, who may be condemned by poor medical treatment to lead a life of dimimished capacity and chromic pain. The presence of this third party provides an obvious challenge to the contract model, with its central tenet that two parties cannot bind a stranger through their own agreement. It is plausible, therefore, that no contract between a medical provider and a woman (with or without the child's father) could bind the infant, who surely has not given any consent of his or her own.

A moment's reflection, however, should be sufficient to dispel any illusion that the prohibition agamst binding strangers by contract applies to the parent/child context. It is true that small children, not to say unborn children, cannot contract on their behalf. Nor have they consented to the tort rules or their no-fault substitutes. The way to escape the difficulties of consent, however, is not witl an elaborate network of state decrees. Rather, the institution of guardianship solves the consent problem, primarily by ensuring that the people with the right mcentives contract on behalf of the young. Parents, by virtue of their status, have obligations not to abuse or neglect an infant and, furthermore, incur affirmative obligations of support.

${ }^{8}$ See Lewis-Idema, Medical Professional Liability and Access to Obstetrical Care: Is There a Crisis?, in Maternal Health, supra note *. 
These obligations surely begin with the labor and nourishment that parents should provide their offspring, but they are not so limited. Parents may also contract with third parties for the benefit of their children, just as they do when they buy their children food at the supermarket, or provide for their education at a public or private school.

The role of guardianship is deemphasized by those who are unsympathetic to contract solutions. Professor Atiyah writes accordingly, "Babies and children are also consumers of health care, and it is a serious question whether the law should allow the rights of children to tort standards of medical care to be bargained away on their behalf by adults." The argument loses its emotive force when it is made clear that not just any "adult" has the power to so bargain. The real question is whether children are better off under the present tort regime created by judges and legislators, than they would be under the alternative contract regime, in which their parents would determine what is in their best interests. If parents are willing to accept the same terms that are applicable to their children, then there is good reason to think that the contract rules will be superior to the tort rules said to protect the children. It is very hard to see how parents can systematically exploit their children when they agree to the same types of legal risks that their children must face. But even where the contract terms are different (because the medical procedures are different), we should be very slow to condemn the variation as a parental sellout of the child's interest. Calling the issue of parental control a "serious question," as Atiyah does, only reaffirms that the issue is important, a point on which everyone can agree. It does not indicate, however, how the question should be resolved. The greater conflict of interest is between the child and the state, not between the child and the parent.

As a matter of sheer necessity, the guardianship arrangement dominates issues of medical care. There is little doubt, for example, that parental consent is what energizes the selection of, and payment for, medical services. It can also work for liability. If parents can inake all other fundamental decisions about the provision of medical care, then why should one element of that set of choices-the terms of

9 Atiyah, Medical Malpractice and the Contract/Tort Boundary, Law \& Contemp. Probs., Spring 1986, at 287, 295. 
compensation if matters go awry-be immune from parental choice? Under the current medical malpractice system, parents are entitled to choose any contingent-fee lawyer to bring suits on behalf of their minor children. Why then should they be powerless to contract out of that tort system for the benefit of their children? After the fact, some parents may regret that choice, just as they regret other decisions made on other matters. But here, as elsewhere, liability rules should be fashioned with an eye not only to compensation ex post, but also to ensuring the access of medical services at affordable prices ex ante. The only variation to the traditional scheme of contracting that is required with regard to medical liabilities to newborns is the recogmition of the guardianship relation. That is hardly an innovation of modern legal theory.

To be sure, there are occasions when the state will override the preferences of parents with regard to their children. These cases, however, fall rather clearly within the traditional area of abuse or neglect. How else should we view a decision to refuse surgical treatment to remove intestinal blockage of a Down's syndrome child, or (of only somewhat more difficulty) to refuse to give to a child medical treatment that is inconsistent with the rehgious behefs of the parents? But, again, the ordinary decisions on how to seek medical care are today most emphatically within the province of the parents, whose natural instincts provide the best shield that most children can ever hope to obtain. Likewise, parents are in the best position to address hability issues on behalf of their chilren.

\section{Access for the Poor}

It may be argued that these contract arguments work for the middle class but do not begin to address the question of access to medical care for indigent families and their children. The concern is that indigent persons, because of their inferior economic status, bring less bargaining power to the contractual negotiations. Again, this point misses the source of the current concern by failing to understand the intimate relationship between access to medical care and tort liability for malpractice. The use of the wrong liability terms has, and will continue to have, a very powerful adverse effect on the level of care made available to people who cannot afford to purchase it. This point can be brought home most clearly if we consider the position of a hospital that supplies charitable care to indigent patients free of 
charge. Historically, these hospitals have, as part of their admission provisions, included conditions that exempted theinselves from any and all hability for physician or hospital neghigence. ${ }^{10}$ These clauses have typically been struck down as an improper form of contractual exploitation of the extraordinary bargaining strength of the hospital. ${ }^{11}$

Nonetheless, judicial condemnation of these charitable exemption clauses seems misconceived. With respect to indigents, a public insistence that a hospital is unable to release itself from medical malpractice liability necessarily reduces the level of access to care in order to increase the level of malpractice protection. Thus, assume that the hospital has a fixed and limited budget that it uses to alleviate the plight of the needy. In a world without any malpractice liability, it could treat, for exainple, 1000 patients, and engage in a level of care that results in ten malpractice cases, for which no one receives any coinpensation. When the ability to contract out of liabihty is barred, some portion of the charitable budget must fund the potential inal-

10 For example, the Supreme Court of California examined the following admissions release form in Tunkl v. Regents of Univ. of Cal., 60 Cal. 2d 92, 383 P.2d 441, 32 Cal. Rptr. 33 (1963):

RELEASE: The hospital is a nonprofit, charitable institution. In consideration of the hospital and allied services to be rendered and the rates charged therefor, the patient or his legal representative agrees to and hereby releases The Regents of the University of California, and the hospital from any and all liabihity for the negligent or wrongful acts or omissions of its employees, if the hospital has used due care in selecting its employees.

Id. at 94,383 P.2d at 442,32 Cal. Rptr. at 34.

11 Thus, the California court struck down the clause in Tunkl, see supra note 10. In his opinion for the court, Justice Tobriner reasoned:

Thus the attempted but invalid exemption involves a transaction which exhibits some or all of the following characteristics. It concerns a business of a type generally thought suitable for public regulation. The party seeking exculpation is engaged in performing a service of great importance to the public, which is often a matter of practical necessity for soine members of the public. The party holds himself out as willing to perform this service for any inember of the public who seeks it, or at least for any member coming within certain established standards. As a result of the essential nature of the service, in the economic setting of the transaction, the party invoking exculpation possesses a decisive advantage of bargaining strength against any inember of the public who seeks his services. In exercising a superior bargaining power the party confronts the public with a standardized adhesion contract of exculpation, and makes no provision whereby a purchaser may pay additional reasonable fees and obtain protection against negligence. Finally, as a result of the transaction, the person or property of the purchaser is placed under the control of the seller, subject to the risk of carelessness by the seller or his agents.

Id. at $98-101,383$ P.2d at $445-46,32$ Cal. Rptr. at $37-38$. 
practice liabilities. Let us assume, therefore, that the number of cases that can be handled decreases by $10 \%$, to 900 , while the imcidence of malpractice decreases by more than half, to $0.433 \%$, so that there are now only four such mcidents.

Which world is the better world for the class of indigents in need of medical care? If we only looked at those persons who in fact received inedical care in both instances, then the choice would seem to be clear: the patient under the malpractice regime is better off on both counts. He receives a higher standard of care, as well as some measure of compensation, if this standard of care is not met. Because the patient wins both ways, the forced judicial invalidation of exculpation clauses looks fully justified.

This analysis, however, is incomplete because it ignores the position of those 100 patients who were unable to obtain care because of the restriction in access caused by the new malpractice regime. If even ten percent of these persons suffered adverse consequences because of their inability to obtain any care, then the conclusion is reversed. The loss of access means that there are now nore in the original cohort of actual and potential patients who sustain bad outcomes under the system with full tort protection than there are in the system that does not provide any protection. $(10+4>10$.) These numbers are chosen for illustrative purposes, such that one cannot have any confidence that the rate of failure will necessarily be greater with liability rules firmly in place. In principle, the errors could run in either direction. It is quite possible that with a medical malpractice system, the level of neghigent treatment will not be cut by more than half; it may be cut by less. It is also possible that many inore than ten percent of people not treated will develop some serious complications. Thus, just as this scenario inay be too grim, it inay also be too optimistic.

It is doubtful, of course, that we shall ever obtain reliable data on the relative strength of the two effects. Nonetheless, three observations can be inade about the current state of affairs. First, the concern with impaired access to medical care is a constant theme of health professionals and administrators who work with indigent patients. They report clinics closing or restricting access to service, and cite the cost of inedical malpractice insurance as one reason for the current distress. It is doubtful that they are grossly wrong in their einpirical 
estimations. $^{12}$ Second, the leading legal decisions that deny the right of hospitals to release themselves from medical malpractice do not even address the interaction between the level of care required and the resulting amount of care that hospitals can then provide. There is no reason, therefore, to think that they have made the correct tradeoffs when they did not identify these tradeoffs in the first place. ${ }^{13}$ Third, there is little reason to think that the hospitals have any perverse institutional incentives on the hability question. The profit motive is surely not dominant in any area in which the institutional purpose is to give away services at some positive cost to itself. Charitable hospitals hardly fall into the class of fast-buck operators, fly-by-night sharpies, or gougers of the poor. It is hard to imagine that prominent donors to medical research would oppose use of their funds for inedical malpractice litigation and damage costs if those expenditures produced any aggregate improvenient in the level of overall medical care provided. There are a very large number of charitable hospitals, and to the extent that they once adopted a uniform set of provisions, it is probably based on the sensible observation that a hability regine does more harm than good to its intended beneficiaries. There is good reason to beheve that they may have been right.

The advent of increased public expenditures on medical care for the poor has changed the situation. Services that were once provided for free are now (at least in principle) paid for by direct government funds. In this context, poor people do not have to bargain for theinselves any more than middle-class people inust bargain when represented by their employers. Public officials that supply the funds can bargain on their behalf in order to obtain the best mix of inedical access and malpractice protection. It is possible that they would want to purchase some malpractice protection for women and children, unborn and born, who are covered by their plans. These agencies face budget constraints that force them to make choices between how

12 This was a constant theme in the discussion sessions at the Research Symposium, supra note *. Few of the speakers who made this assertion had a strong intellectual orientation toward markets.

13 See Madden v. Kaiser Found. Hosps., 17 Cal. 3d 699, 552 P.2d 1178, 131 Cal. Rptr. 882 (1976). Note that insurance companies are often unwilling to provide additional coverage against loss for an additional premium because of the risk of adverse selection-that is, those persons who are likely to demand the coverage are the most likely to sue. The practice, therefore, is to make the coverage constant across broad classes of cases. See R. Epstein, Epstein, Gregory \& Kalven's Cases and Materials on Torts 44 n.3 (Supp. 1987). 
much money they wish to spend on preserving access and how much they wish to spend on assuring compensation when medical care turns out to be inadequately provided. They are, of course, subject to the same bureaucratic himitations inherent in all public agencies, but if we are prepared to accept their role in other aspects of medical care, then I am hard pressed to see why they could not be allowed to contract as agents for their beneficiaries on tort hability.

Yet how would they proceed? Welfare agencies also face heavy budget constraints, and must make the same tradeoffs between access to the system and the level of protection afforded to those lucky enough to make it into the system. The official involved might make the same decision desired by middle-class persons, and therefore stipulate for some particular malpractice compensation scheme. There seems to be no reason why public agencies could not insist that all malpractice disputes go to arbitration, as can now be done by private employers. ${ }^{14}$ Indeed, there is no reason to tie the fortunes of the poor to the tastes of the middle class. The desire for greater legal protection agamst medical malpractice may well reflect middle-class patients' greater willingness and ability to pay. There seems to be no reason to assume that poor people have the same preferences, given their far lower levels of income. Hence, poor people should not be forced to enter into exactly the same kind of contracts. I would therefore allow the public officials virtually complete contractual freedom in the kinds of medical services contracts that they negotiate for the poor. The argument here is not that the "no liability solution" of bygone days is necessarily best. It is that the persons in charge of the programs have better inforination about the optimal set of contract terins than that of legislatures or courts, and even (dare one say it) than that of public policy analysts and law professors.

14 Carter Phillips, speaking on behalf of the American Medical Association (joined with 30 other medical groups), made this point very clear in his oral presentation at the Research Symposium, supra note *, "Proposed Alternative to the Civil Justice System for Resolving Medical Liability Disputes," to be published in Maternal Health, supra note *. Phillips, like $\mathrm{me}$, is doubtful that any major restructuring of medical malpractice laws can be limited solely to obstetrics and gynecology. See id. 


\section{The Virginia No-Fault Statute}

\section{A. The Political Setting}

My defense of contractual regimes for medical malpractice certainly does not represent today's dominant opinion. Quite the opposite, the first question-who should decide what the rules are-is answered routinely in favor of plenary state authority. Political action focuses on the second question-what rules the state should impose. Given this particular framework, it is quite clear that the legal solutions will no longer have the same type of generality, efficiency, and (if it matters) elegance of the contractual solution. Instead, the pattern of behavior will be quite different because it will now be necessary to contend with the dynamics of interest-group pohtics, as life-and-death questions ensure that both emotions and stakes will be high.

The first rule of politics is that general solutions are often very hard to achieve because there will be no sponsors to introduce them. Political action does not start with overarching philosophical theories. It is galvanized by crisis, by dramatic incidents, and by the sense of dire necessity. The Injured Infant Act, providing for no-fault insurance in certain obstetrical cases, is illustrative of the general process. Over the years, there has been a large number of attempts to formulate comprehensive medical no-fault proposals, ${ }^{15}$ and these have routinely floundered on the inability of anyone to define the universal class of compensable events-that is, those for which the new habilities would be imposed-with a level of precision that makes the system workable in the broad run of cases. ${ }^{16}$ There have been, lowever, nany wellpublicized judgments or settlements against individual obstetricians for huge verdicts, beyond the levels of insurance they carry, and perhaps beyond their net worth. ${ }^{17}$

15 See, e.g., sources cited supra note 2.

16 See, e.g., Abraham, Individual Action and Collective Responsibility: The Dilemma of Mass Tort Reform, 73 Va. L. Rev. 845, 886-89 (1987); Keeton, Compensation for Medical Accidents, 121 U. Pa. L. Rev. 590, 605, 612-14 (1973).

17 For example, a 10 million dollar verdict against three prominent obstetricians in Washington, D.C. prompted their patients and colleagues to rally around them on appeal. The verdict exhausted the obstetricians' insurance coverage and, if it had been upheld on appeal, may have forced them into bankruptcy. Colleagues Rally For 3 Doctors Ordered To Pay $\$ 10$ Million, Wash. Post, June 4, 1988, at A1, col. 1. The case, however, was settled for $\$ 4$ million-the limit of the obstetricians' coverage-as well as for $\$ 800,000$ paid separately by the hospital. Wash. Post, Sept. 10, 1988, at B1, col. 1. 
Initially, there is something very wrong with a system that says to a physician: "Thank you for saving by timely and courageous intervention nmety-nine children from terrible fates and ruined hives. You have earned your fee." Yet when the 100th child (even because of negligence) suffers a similar terrible fate, we say, "Pay its full costs." The scorecard that summarizes the results looks odd indeed. The net social benefit equals ninety-nine lives spared a terrible fate; the physician's scorecard shows routine fees in minety-nine cases, wiped out by the huge losses on the last case. There is a manifest divergence between the private loss that the physician bears and the net social gain that the physician's activities produce. Actions that, on balance, everyone would favor ex ante-for example, having the physician do medical procedures that succeed ninety-nine percent of the time and negligently fail one percent of the time-generate financially ruinous results for the physician. The expenses in the one case dwarf the fees in the nimety-nine others. The source of the gap is clear. The medical malpractice system does not explicitly credit the physician for the benefits provided in the ninety-nine cases of successful medical intervention. Yet individuals in making private decisions of whether to accept or reject medical care will regard that benefit as more important than whether compensation will be forthcoming ex post for the timy fraction of cases that go wrong. ${ }^{18}$

The question that emerges in the legal system is this: Once the medical malpractice system puts the wrong rules for compensation in place in the obstetrical area, what can be done to undo the damage?

18 Clearly, this numerical example is dependent on the assumption that most medical interventions are beneficial today. That assumption seems to be unquestionable even if the exact ratio is subject to doubt. But even if the numbers were 98 to 2, the net positive would still be very large, and the analytical point would remain the same. Benefits conferred are not ignored in any ex ante calculation. In addition, if the percentage of negligence cases were much higher, then the system would collapse under its weight. The frequency of malpractice litigation would be unbearable if, for example, two percent of surgeries resulted in malpractice litigation. If the average surgeon performed 100 .surgeries per year, there would be two cases per year. If each suit lasted five years, then the average surgeon would be a defendant in 10 cases at one time. Even the present frequency of litigation is far lower than this.

It has been suggested that the real torts crisis is that too few victims sue. See Abel, The Real Tort Crisis-Too Few Claims, 48 Ohio St. L.J. 443 (1987). Abel relies on the work of Patricia Danzon, showing that $90 \%$ of the incidents of medical negligence do not result in any legal action. See id. at 448 (citing P. Danzon, supra note 4, at 19-21, 23). Danzon's figures suggest that nationwide there was in 1974 an annual total of 260,000 negligently inflicted injuries out of over 1,500,000 iatrogenic injuries. See P. Danzon, supra note 4, at 20. If all these injuries resulted in suits, as Abel urges, it would overwhelm the system. 
Private responses are surely possible, though not ideal. Fees can be raised to cover the mishaps, but they are limited by the wealth of the patients, a dominant concern for many imdigent patients. Moreover, patients' wealth limits the purchase of additional safety precautions. If the situation gets bad enough, the movement will then be for legislation, which is what apparently prompted the passage of the Virgima Injured Infant Act. ${ }^{19}$ A close look at this novel statute reveals some of the compromises that had to be made to secure its passage and some of the serious defects in its basic structure. ${ }^{20}$

\section{B. The Statutory Design}

The Virginia Injured Infant Act is restricted to one class of major mjury:

"Birth-related neurological injury" means injury to the brain or spinal cord of an infant caused by the deprivation of oxygen or mechanical injury occurring in the course of labor, delivery or resuscitation in the immediate post-delivery period in a hospital which renders the infant permanently nonambulatory, aphasic, incontinent, and in need of assistance in all phases of daily living. ${ }^{21}$

The statute provides measures to collect and distribute the funds necessary to handle this important class of cases. First, the disposition of claims is taken out of the tort system (with its jury trials) and placed before the State Industrial Commission, ${ }^{22}$ whose usual responsibility is to hear workers' compensation claims, which themselves often raise substantial medical issues. Second, there is a network of substantive provisions. Most notably, funds for the program are raised by a perhead flat fee of $\$ 5000$ for individual obstetricians who choose to participate in the program. ${ }^{23}$ This fee is fixed by statute for the first year ${ }^{24}$ and cannot be raised in subsequent years, apparently even for inflation. ${ }^{25}$ The fee for hospitals is $\$ 50$ per delivery per year, subject

19 For a commentary on this Article that reveals the ideas and pressures underlying the initial drafting of the Injured Infant Act, see O'Connell, Pragmatic Constraints on Market Approaches: A Response to Professor Epstein, 74 Va. L. Rev. 1475 (1988).

20 For a fuller discussion of the content and passage of the statute, see Note, Innovative NoFault Tort Reform for an Endangered Specialty, 74 Va. I. Rev. 1487 (1988).

21 Va. Code Ann. § 38.2-5001 (Supp. 1987).

22 Id. § 38.2-5003.

23 Id. § 38.2-5019(A)(1).

24 Id.

25 Id. $\S 38.2-5020(\mathrm{~A})$. 
to an overall cap of $\$ 150,000$ per hospital. ${ }^{26}$ Physicians who do not participate in this program are nonetheless required to contribute $\$ 250$ per year to the fund. ${ }^{27}$ If the funds raised from these three sources are insufficient to cover the obligations under the program, then the resultant shortfall will be covered by taxes levied on all insurance companies within the state, whether or not they are in the business of providing coverage for medical malpractice. ${ }^{28}$

As to the distribution of benefits from the plan, the patterns of compensation adopted parallel those used in workers' compensation plans. The statute provides no compensation for pain and suffering; ${ }^{29}$ it provides limited compensation for lost earnings, based upon fifty percent of the average weekly wage, as well as for medical and other support services over the life of the program, with setoffs, dollar for dollar, for collateral sources under the plan. ${ }^{30}$

Participation in this program is not mandatory for pliysicians or hospitals. They are permitted to opt into the system at their free will. If they agree to participate, lowever, the level of services that they provide is subject to review by a Board of Directors, which administers the Injured Infant Act $^{31}$ The pliysicians and hospitals must also agree to participate in developing a program to provide obstetrical care to indigent patients. ${ }^{32}$ Curiously, neither physicians nor hospitals seem to be required to disclose to their patients their decision to participate in the plan.

It is instructive to compare the political solution reached by the Injured Infant Act to that which might be reached under market arrangements. The analysis is conveniently divided into two parts: coverage and funding. I take them up in that order.

\footnotetext{
26 Id. $\S 38.2-5019(\mathrm{~A})(2)$.

27 Id. $\$ \S 38.2-5019(\mathrm{~A})(3)$ to $-5020(\mathrm{~A})$.

28 Id. $\S 38.2-5020$ (B). The collections are made "if required to maintain the Fund on an actuarially sound basis." Id.

29 See id. \$ 38.2-5009.

30 Id.

31 Id. $\S 38.2-5001$. As appointed by the Governor of Virginia, the Board shall consist of a general citizen's representative and of representatives of the other interest groups under the plan-participating hospitals, participating physicians, liability insurers, and nonparticipating physicians-such that the majority of the Board represents its participants. Id. \$ 38.2-5016.

32 Id. $\S 38.2-5001$. It is certainly worth noting that the obligation to so participate is not made a separate substantive provision of the statute, but is incorporated into the definition of a "participating" physician or hospital.
} 


\section{Coverage}

The coverage provisions here are restricted to only one class of serious injuries. Why is only this class included when other types of injuries might well be as serious? From the point of view of an outsider, one possible answer is that problems arising in this class of cases were so pressing that the legislature was forced to take it specifically in hand, leaving the others to the malpractice system. Indeed, if there are an estimated forty such cases per year, ${ }^{33}$ then the dollars involved are in fact quite large. Each case under the program could easily generate present habilities of several million dollars. Another explanation, with perhaps more descriptive power, is that the compromise was necessary to get the bill through the Virginia legislature. Trial lawyers form a powerful interest group in all states, and they could well have blocked the more general removal of all obstetrical cases from the medical malpractice system; after all, they do not want a precedent that ends malpractice altogether.

A contract solution would doubtless be more general in its coverage. Ex ante, the dominant question is whether both sides are better off by taking cases out of the tort system and providing some alternative system for compensation. Costs of prevention, needs for compensation ex post, and admimistrative costs of the system are likely to control that inquiry. If that is the case, then there seeins to be little reason to differentiate by source within the class of severe injuries. Although it may not be clear exactly how all severe injuries would be covered, it is a good guess that they would all be covered im the same way.

There is also a question whether this choice of compensable events covered by the statute makes sense. Here, the definition on its face appears quite narrow, being restricted to "injury to the brain or spinal cord of an infant caused by the deprivation of oxygen or mechanical injury occurring in the course of labor, delivery, or resuscitation." 34 The operative concern is not semantic because the meaning of the terms is as clear as good legal draftsmanship could make it. Instead, the issue is an empirical one: What is the percentage of all birth defect

33 See Memorandum from Kenneth V. Heland to the American College of Obstetricians and Gynecologists Committee on Professional Responsibility (Mar. 5, 1987) (on file with the Virginia Law Review Association).

34 Va. Code Ann. \& 38.2-5001 (Supp. 1987). 
cases that will be contestable under the definition? In order to answer this question, one must know a lot more about medicine than any outsider to the profession knows. Nonetheless, it is possible to at least note two sources of concern that might be raised about this warranty. ${ }^{35}$ First, it is often difficult to distinguish serious injuries caused at or before birth from those caused by birth defects. The ultimate physical condition that results in the two kinds of cases is often the same in either case (for example, brain damage) although the medical evidence is not reliable enough for anyone to make an accurate determination on causation. Second, it may be that certain serious fetal injuries can be caused by intermittent drug (for example, cocame) use, which could not be distmguished from the compensable injuries under the statute. Here, the problem turus out to be especially acute because there now seems to be ample data suggesting that even a smgle "hit" of cocame in the first trimester of pregnancy can cause massive neurological damage, even though it might be very difficult to trace the results thereafter. ${ }^{36}$ Moreover, the incidence of maternal use of illegal drugs, mcluding cocaine, during early pregnancy is very high, and has been estimated to be as much as eleven percent. ${ }^{37}$ Under a system of neghigence liability, it is unlikely that even a tiny fraction of these cases would create a colorable case for liability. Under this statute, all of them do, especially if there is no trace of cocaine or other drug left in the child's system six months later when birth occurs. It seems most unlikely that the Virgimia no-fault plan was intended to be a compensation program for victims of maternal drug abuse. Yet that is the risk it creates.

35 These issues were raised in a discussion by Donald N. Medearis, Jr., of the Department of Pediatrics at Harvard Medical School and Chief of Children's Service at Massachusetts General Hospital, and Ruth Watson Lubic, Ed.D., General Director of the Maternity Center Association, in New York, at the Research Symposium, supra note *.

36 According to one commentator:

In fact, the research suggests that a single cocaine "hit" during pregnancy can cause lasting fetal damage. While a single dose of cocaine and its metabolites clear out of an adult body within 48 hours, an unborn baby is exposed for four or five days. . . .

Cocaine, which is soluble in fat, readily crosses the placenta, where the baby's body converts a significant portion of it to norcocaine, a water-soluble substance that does not leave the womb and that is even more potent than cocaine. Norcocaine is excreted into the amniotic fluid, which the fetus swallows, re-exposing itself to the drug. As a result, the researchers believe, almost no cocaine-exposed baby fully escapes its damaging effects.

Brody, Cocaine: Litany of Fetal Risks Grows, N.Y. Times, Sept. 6, 1988, at 19 (Chicago ed.). 37 Id. at 19, 23. 
The Virginia Injured Infant Act seeks to handle these problems by using rebuttable presumptions: "A rebuttable presumption shall arise that the injury alleged is a birth-related neurological injury where it has been demonstrated, to the satisfaction of the Industrial Cominission, that the infant has sustained a brain or spinal cord injury caused by oxygen deprivation or mechanical injury." 38 The initial presumption appears to be set in favor of the physician, until the Commission makes the critical finding (which should not be made in drug cases) that the bram or spinal cord mjury is attributable to oxygen deprivation or spinal injury. Yet that question of fact can be highly controverted, and although presumptions can shift burdens, they do little to reduce the total level of error. At most, presumptions only determine whether the large residual errors that uncertainty creates are borne mainly by plaintiffs or defendants. The drug cases could still arise with sufficient frequency to inundate the whole system. If the gray area under the statute turns out to be very large for medical reasons, then clarity of draftsmanship will offer no refuge from an administrative nightmare, or from the strategic maneuvers of both sides.

In addition, other complications may arise. Thus, the claimant who thmks negligence is clear will try to keep the case outside the statute, whereas the defendant will try to bring it within the statute. Yet nothing in the statute deals with this reversal of roles, which is familiar to lawyers who work in workers' compensation cases. Ironically, a negligence standard, for all its flaws, may turn out to be inore desirable, if only because fewer cases straddle the negligence/no negligence line than straddle the iatrogemic injury/birth defect or drug usage line. But under the statute, we have no market information and, hence, no capacity for incremental adjustments $m$ the basic rules. There will have to be another obstetrical crisis before there can be corrective action.

\section{Funding}

Equally striking are the provisions that address the funding of the system as a whole. In market settings, any contract must work for the joint benefit of the parties. There may be an uneven distribution of the gains from trade, but each side will garner at least some portion of those gains. Ex ante, there should be no losers. Legislation must not

38 Va. Code Ann. § 38.2-5008(1) (Supp. 1987). 
satisfy that constraint, especially as the level of constitutional safeguards to economic liberties and property today is set at a very low level indeed. ${ }^{39}$ Hence, we should expect to see large amounts of wealth redistribution take place within the system.

Initially, the fees charged do not begin to approximate the risks that are covered. The Injured Infant Act does not reveal a budget estimate as to the total likely expenses, which is then made the target for the total charges imposed against the participants to the system. Quite the opposite, the statute contemplates that any shortfall that may develop shall be covered by all insurance carriers within the state, regardless of the lines of business they write. Here, the physicians as a group are able to impose huge contingent (but very real) liabilities upon insurance carriers who write only other unrelated lines of busmess. The provision that insulates plan participants from any historically justified rate increases makes it clear that the real question is not whether, but when, the contingent liability will kick in. This financing decision is not without its negative allocative consequences. The imposition of taxes always distorts market decisions in the goods or cominodities that are taxed. When unrelated lines of insurance are subject to taxes, they becoine less available to the consumers who benefit from them, as the tax drives from the marketplace all transactions in which the difference between the buyer's gain and the seller's cost is less than the tax in question..$^{40}$ Large taxes therefore tend to work large misallocations. But insurance coinpanies are an easy populist target for attack, and their customers are too diffuse to protest. The statutory financing scheme therefore exports misery. It does not ehminate it.

The usual somber conclusion of the public choice literature holds here. ${ }^{41}$ The efforts in the political process to correct one distortion, such as the medical malpractice tort rules, only create other distor-

39 For the modern statement, see Usery v. Turner Elkhorn Mining Co., 428 U.S. 1 (1975). I have criticized this approach at length in R. Epstein, Takings: Private Property and the Power of Eminent Domain 256-58 (1985), and more briefly in Epstein, Self-Interest and the Constitution, 37 J. Legal Educ. 153 (1986) and Epstein, Judicial Activism: Reckoning of Two Types of Error, 4 Cato J. 711 (1984).

40 For a discussion of the so-called excess burden of taxation, see J. Gwartney \& R. Stroup, Economics: Private and Public Choice 110-11 (4th ed. 1987).

41 For the classical elaboration, see J. Buchanan \& G. Tullock, The Calculus of Consent (1962). For the modern controversy, see Symposium on The Theory of Public Choice, 74 Va. L. Rev. 167 (1988). 
tions in other markets. Even the sage cannot hazard a guess as to which set of distortions is greater. But the ordinary analyst can say with confidence that competitive markets in both sectors yield a better social solution.

The redistribution provided by the statute works in more than one direction. In order to extract profits from insurance companies, the obstetrician groups had to make deals with other legislative interest groups, and they did. With whom the deal was made, it is hard for an outsider to say. But surely, welfare and children's rights groups and some segments of the medical and insurance industries are likely candidates. The evidence appears on the face of the statute. The definition of a participating physician or hospital includes only those willing to participate im developing programs to assist the poor: limited public service has become the quid pro quo for reduced tort liability. Here, I do not wish to quarrel with public assistance as such. But why should it be funded from special taxes on obstetricians and hospitals? In a sense, the odd funding of this statute is a quid pro quo for getting out of the tort system, in which they should have never entered. The new principle is that bad common law rules are corrected only if the losers pay tribute to the legislature that relieves them of their pains. (It is as if justice is done when the thief agrees to sell back stolen property to its owner at a below market price.) The Byzantine system of indirect payments that emerges results only in public mischief because no one ever must make an explicit public reckonimg of what resources should go to welfare generally, or why. The political system thus generates a set of hidden taxes and offbudget appropriations with which no citizen can keep pace. ${ }^{42}$ How ironic it is that private contracts are attacked on the ground that consumers have imperfect information! The statute is drafted in a way to keep its real costs hidden from public view.

Not only does the redistribution worked by the statute take place between sectors, but it also occurs within the medical sector. Physicians are forced to contribute to the plan, whether or not they benefit from participation. Yet, in ordmary private insurance markets, there are powerful incentives to differentiate in cost of coverage for different

\footnotetext{
42 For a related discussion concerning AIDS, see Epstein, The AIDS Commission's Hidden Tax, Wall St. J., June 13, 1988, at 12.
} 
insureds. ${ }^{43}$ The insurance company that can identify low risk providers of medical services and offer them premiums to match those services will eliminate any implicit subsidy of inefficient producers by efficient producers. The legislated insistence upon a flat fee prevents this particular program from having its desired effect. Now, physicians with routine practices are forced to subsidize their colleagues who specialize in high-risk pregnancies. Moreover, the same implicit redistribution can take place, for example, between small community hospitals that do not derive any benefit from the hospital cap and large university hospitals, with a far riskier patient mix, that do. In principle, these subsidies are all inefficient, and at least with respect to institutions, the plan should be modified to allow experience-rating if data proves reliable enough to sustain it.

What about the consumer of medical services? In one sense, the statutes in question do not mark a move to consumer consent. The physician or hospital can opt into this system at its own will, but it appears that the statute does not even require them to inform their patients of the choice. At the very least, a provision that requires very clear disclosure would be some improvement because medical providers would have to gauge the effect of their choices on their ability to maintain their practices. Even if the patients should unanimously approve the abandonment of the malpractice system, however, we could not be confident that the system represents a social improvement, given the huge implicit subsidies (especially from insurers and less so from nonparticipating physicians) built into the plan.

\section{CONCLUSION}

The total picture is at best cloudy because it is not clear whether in the aggregate this no-fault situation is better or worse than the malpractice situation that it replaced. That malpractice system tended to make every serious birth injury a tort suit, so that the skilled specialist physicians and large hospitals suffered disproportionate losses. This no-fault system hopes to correct that set of distortions, but only at the expense of creating other distortions that may be as serious as the

43 For a general account of the operation of private insurance markets with respect to liability, see Epstein, Products Liability as an Insurance Market, 14 J. Legal Stud. 645 (1985); Schwartz, Proposals for Product Liability Reform: A Theoretical Synthesis, 97 Yale L.J. 353 (1988). 
ones that are eliminated, if not more so. The point here is not that the system is not perfect; no system is. Rather, it is that the system, especially with active legislative intervention, is more politically charged, and more imperfect, than it need be.

Relative to Virginia's Injured Infant Act, markets have two great strengths that are often underappreciated. First, they allow some experimentation for ideal contractual terms, which could provide for solutions better than those of either the medical malpractice system or its limited no-fault alternative. Second, markets weed out all the implicit subsidies that legislatures and interest groups are routinely able to work into their deals. These advantages are not simply abstract or theoretical. They increase the capacity of the society to provide needed goods and services for all its citizens. In the clamor for short-term reform, the overall social effects are often ignored in favor of more insistent, and more parochial, considerations. Two wrongs do not make a right. State-mandated no-fault statutes are not the right response to the blunders of the present malpractice system. Markets are. 